\title{
Technical Efficiency of Malaysia's Development Financial Institutions: Application of Two-Stage DEA Analysis
}

\author{
Raj Yadav $^{1} \&$ Mohamed Nasser Katib ${ }^{1}$ \\ ${ }^{1}$ School of Economics, Finance \& Banking, Universiti Utara Malaysia, Sintok, Kedah, Malaysia \\ Correspondence: Raj Yadav, School of Economics, Finance \& Banking, College of Business, Room 002, Ground \\ Floor, Business Management Building, Universiti Utara Malaysia, 06010 UUM, Sintok, Kedah, Malaysia. Tel: \\ 60-4-928-6921. E-mail: rajyadavjnu@gmail.com; nasser@uum.edu.my
}

\author{
Received: February 19, 2015 Accepted: June 3, 2015 Online Published: June 13, 2015 \\ doi:10.5539/ass.v11n16p175 URL: http://dx.doi.org/10.5539/ass.v11n16p175
}

\begin{abstract}
This paper investigates the technical, pure technical, and scale efficiency of 9 development financial institutions (DFIs) operating in Malaysia from 2006-2012 and factors affecting the efficiency of development financial institutions, using the two-stage data envelopment analysis (DEA). Results revealed that the mean technical efficiency of DFIs in Malaysia is 78 percent. Two banks namely BPMB and SCC are the benchmark banks identified by DEA scores. Results show that the role of scale inefficiency in overall technical inefficiency is comparatively less than managerial inefficiency. Results also show that only BPMB, SCC experienced constant returns to scale for the period 2006-2012, fulfilling their primary objective of contributing towards the socio-economy development of the state. BSN, a major saving institution, experienced decreasing returns to scale in 2009 and 2012. SME bank, whose mission is to develop SMEs, too experienced decreasing returns to scale during 2009-2010. CGC and Agro bank also experienced decreasing returns to scale in 2008-2009 and 2010-2012. In second stage, results of the OLS regression analysis provides that Loans to total assets, natural logarithm of total assets, Loan-Loss provision to total loans, non-interest income to total assets, return on assets and total shareholders' equity to total assets are related to technical efficiency but loans to total assets, positively related to technical efficiency and significant and shows that banks with higher loan to asset ratios tend to have higher technical efficiency scores; non-interest income to total assets is negatively related to technical efficiency and significant revealing that development financial institutions which derive a higher proportion of income from non-interest sources tend to report lower efficiency scores. Return on assets are found significant in explaining the Malaysian development financial institutions efficiency from 2006-2012.
\end{abstract}

Keywords: development financial institutions, technical efficiency, pure technical efficiency, scale efficiency, data envelopment analysis, ordinary least squares (OLS) regression analysis

\section{Introduction}

Financial intermediaries provide financial services like payments, liquidity, store of value, divisibility, maturity transformation, risk pooling and information economies. Banks are the main intermediaries that provide a majority of the core financial services. However, they do not provide all services efficiently equally. Non-bank financial institutions (NBFIs) particularly development financial institutions supplement banks by providing services in the form of development finance, that are not well suited to banks. Function of development finance is to categorize the cracks in establishments and markets in a country's financial sector and acts as a concealer and is thus targeted at economic agents, which are rationed out of market. The vehicle for extending the development finance is popularly known as the development financial institution (DFI) or development bank.

Development financial institutions in Malaysia are established by the government with specific mandates. DFIs not only assist the Malaysian government in developing and promoting the identified strategic sectors of the economy e.g. agriculture, micro, small and medium enterprises, infrastructure, etc. but also act as a catalyst in achieving socio-economic goals by complementing the role of the banking institutions (Chew, 2011). By 2020, Malaysia seeks to achieve a status of high value-added and high income economy and Malaysia's small and medium enterprises (SMEs) that act as a backbone of Malaysian economy, have an indispensible role to play, with nearly $99 \%$ of total establishments contributing $32 \%$ of Malaysia's GDP, generating $59 \%$ of employment and $19 \%$ of exports. By 2020 , estimates show that SMEs in Malaysia will be contributing $41 \%$ of GDP, 
employing $62 \%$ of population and promoting $25 \%$ of the exports. Thus, DFIs in Malaysia like Small and Medium Enterprise (SME) Development Bank Malaysia Berhad (SME Bank), Bank Simpanan Nasional (BSN), and Bank Pertanian Malaysia Berhad (Agrobank) and other DFIs that cater to the needs of entrepreneurs in the agricultural sector and focus on the provision of micro-financing to micro enterprises have a major role to play in making Malaysia a high value-added and high income economy in the future.

\section{Literature Review}

There is a plethora of literature evaluating the performance of financial institutions particularly banking institutions. Financial ratio analysis, data envelopment analysis, and the stochastic frontier analysis are the few frequently and widely used approaches to analyze the financial performance of the banks. Hamid \& Azmi (2011), Bader Shamser \& Taufiq (2007), Hassan and Bashir (2003); Rosely, Mohd. Afandy (2003); Samad (1999); Akkas (1996); and Arif (1989), in their study used financial ratio analysis to assess the financial performance of banks. DEA, another approach led by Charnes et al. (1978), utilized by researchers as a methodology for performance evaluation (Gregoriou \& Zhu, 2005). Applying DEA, Sherman and Gold (1985), and Parkan (1987) analyzed the efficiency of branches of US and Canadian banks, respectively. Rangan et al. (1988) analyzed the pure technical inefficiency and scale inefficiency of 215 US banks. Their results showed that the same amount of output could have been produced by banks with 70 per cent of the inputs and the cause of inefficiency was primarily technical. Yue (1990) examined the efficiency of banks in Missouri, US (1984-1990), and found that the major source of overall technical inefficiency was pure technical inefficiency. Efficiency of 143 Japanese banks was examined by Fukuyama (1993) using the DEA method. Findings showed that the banks were more scale efficient compared to pure technical efficient (PTE). Study by Yudistria (2003) who also applied DEA to examine the technical, pure technical, and scale efficiency of Islamic banks found that diseconomies of scale for small-to-medium Islamic banks existed and therefore mergers were encouraged; and Drake et al. (2006) used a combination of slack-based Tobit regression approach with DEA to examine the impact of macroeconomic and regulatory factors on the efficiency of Hong Kong banking system. This study concluded that there was an existence of high level of technical inefficiency for many institutions and also differential impacts of environmental factors on different size groups and financial sectors. Studies focusing on Malaysian development financial institutions are few; among them was a study by Islam (2012) who utilized the most commonly traditional financial ratio approach to assess the financial performance of two DFIs in Malaysia and found that the financial health of the two DFIs was sound but comparatively, Bank Rakyat was in a better position than its peer, Bank Simpanan Nasional (BSN). Ong et al. (2005) used a non-parametric technique to determine the scale and technical efficiency of four development financial institutions and CGC in Malaysia over a period of 1981-1998 and found that the DFIs were operating satisfactorily in extending their services to small and medium local enterprises. Fadzlan (2006) utilized DEA to investigate the efficiency of Malaysian non-bank financial institutions over a period of 2000-2004 and found that the finance companies' mean overall efficiency was greater than merchant banks' mean overall efficiency and also showed that pure technical inefficiency rather than scale inefficiency resulted in Malaysian NBFIs overall inefficiency.

Among the above mentioned studies, few studies have focused on efficiency of DFIs in Malaysia. Therefore, our study is going to use the two stage analysis of DEA, where in the first stage the technical efficiency of nine DFIs in Malaysia over a period of 2006-2012 will be examined and then in the second stage, OLS will be applied to determine the factors affecting the efficiency.

\section{Research Methodology}

The non-parametric DEA method, first introduced by Charnes et al. (1978), will be used to measure the input-oriented technical efficiency of the DFIs in Malaysia. The CCR (Charnes, Cooper and Rhodes) model calculates an overall efficiency for the unit in which both its pure technical efficiency and scale efficiency are amassed into a single value assuming constant returns to scale (CRS) and CRS hypothesis is acceptable when all decision making units (DMUs) are functioning at an optimal scale. But, institutions like banks face either economies or diseconomies of scale. Thus, assuming Constant Returns to Scale, the calculated measures of TE will be contaminated with scale efficiency (SE) when all DMUs are not functioning at an optimal scale. Beyond CCR, Banker et al. (1984) introduced another model BCC (Banker, Chames and Cooper) by relaxing the CRS assumption. Assumption of Variable Returns to Scale provides the measurement of PTE. An observable deviance among the Technical efficiency and Pure Technical Efficiency scores of DMUs shows the presence of Scale inefficiency, i.e., Technical Efficiency $=$ Pure Technical Efficiency $\times$ Scale efficiency. Pure Technical Efficiency is related to the capability of managers to use banks' given resources, and scale efficiency is related with exploiting scale economies by operating at constant returns to scale. 


\subsection{Multivariate Regression Analysis}

One drawback with the DEA methodology is that it infers random errors as inefficient, that makes it complex to outliers and degrees of freedom. Studies by Banker (1993) and Banker and Natarajan (2004) stated that the efficiency $\theta_{i}$ is a consistent estimator and was found that the use of a two-stage procedure using DEA followed by an ordinary least square (OLS) regression gives consistent estimators of the regression coefficients (Banker \& Natarajan, 2008). Following Sufian (2010), equation (1) is estimated by using the Ordinary Least Square method. Technical efficiency scores are used as the response variable, and the subsequent multivariate model is estimated:

$$
\begin{array}{r}
\lambda j t=\delta_{0}+\beta_{1} \mathrm{LN}\left(\mathrm{LOANS} / \text { Total Assets) } j t+\beta_{2} \mathrm{LN}\left(\text { Total Assets) } j t+\beta_{3} \mathrm{LN}(\text { Loan-Loss Provision/Total Loans }) j t+\right.\right. \\
\beta_{4} \mathrm{LN}\left(\mathrm{N} \text { (Non-Interest Income/Total Assets) } j t+\beta_{5} \mathrm{LN}(\text { EQASS }) j t+\beta_{6} \mathrm{LN}(\mathrm{ROA}) j t+\varepsilon j t\right.
\end{array}
$$

where ' $i$ ' depicts the DMU(bank), ' $t$ ' the time period, and is the disturbance term. In order to measure bank's loans intensity, LOANS/Total Assets, calculated as the ratio of total loans to total assets; LNTA is used as a proxy measure of bank size in terms of total bank assets; Loan Loss Provision/Total Loans, a measure of bank's credit risk is calculated as the ratio of total loan loss provisions divided by total loans; Non-Interest Income/Total Assets, a measure of bank diversification towards non-interest income; EQASS is used as a representation measure of bank's capitalization level and ROA is a representation measure for bank's profitability.

\subsection{Specifications of Bank's Input, Output and Data}

Two popular approaches normally used to evaluate efficiency in banking are production and the intermediation approach. Benston in 1965 introduced Production approach, that consider banks provide services to customers whereas Intermediation approach accepts that financial firms act as an intermediary between savers and borrowers and posits total loans and securities as outputs, and deposits along with labor and physical capital are defined as inputs. Charnes et al. (1990), Bhattacharyya et al. (1997) and Sathye (2001) adopted intermediation approach. Berger and Humphery (1997) proposed that the intermediation approach is best suited for analyzing bank level efficiency, whereas the production approach is well suited for measuring branch level efficiency.

This proposed study will be using the secondary data of nine Development Financial Institutions (Bank Pertanian Malaysia Berhad (Agrobank), Bank Kerjasama Rakyat Malaysia Berhad (Bank Rakyat), Bank Pembangunan Malaysia Berhad Bank (BPMB), Bank Simpanan Nasional (BSN), Malaysian Industrial Development Finance Berhad (MIDF), Sabah Credit Corporation, Bank Perusahaan Kecil \& Sederhana Malaysia Berhad (SME Bank), Credit Guarantee Corporation Berhad (CGC), and EXIM Bank) annual reports for the period of 7 years (2006-2012). This study is restricted to nine DFIs because of data unavailablity. Under intermediation approach, 2 inputs and 2 outputs are chosen for each development financial institutions.

Input A $\left(\mathrm{x}_{1}\right)=$ Total deposits,

Input $\mathrm{B}\left(\mathrm{x}_{2}\right)=$ Total expenses,

Output $\mathrm{A}\left(\mathrm{y}_{1}\right)=$ Loans, financing and advances,

Output B $\left(\mathrm{y}_{2}\right)=$ Net investments.

\section{Empirical Finding}

This section is going to discuss the technical efficiency (TE) of the development financial institutions, through DEA method and further breaking down to Pure Technical efficiency (PTE) and Scale efficiency (SE) components. Table 1,2,3 and 4 provides a summary of technical, pure technical and scale efficiency estimate results. Table 1 (refer appendix) findings show that the mean TE of the Malaysian Development financial institutions ranges between 71 percent in 2009 to 87.1 percent in 2010. Findings suggest that relative to their cost frontier, DFI's of Malaysia have been operating at 12.9 percent to 29 per cent above minimum cost levels. Findings of Table 1 show that BPMB and SCC are the most efficient development financial institutions with mean technical efficiency of 100 percent. BSN is close to efficiency frontier with mean technical efficiency of 94 percent. Development financial institutions that require improvement to be efficient are the SME, MIDF, Bank Rakyat, Agro Bank, CGC and EXIM Bank.

Breakdown of TE into Pure Technical efficiency (PTE) and Scale efficiency (SE) shows that Scale inefficiency (SIE) has major implication as a source of inefficiency than Pure Technical Inefficiency (PTIE). It is observed from Table 2 (refer appendix) that Malaysian development financial institutions have exhibited a mean PTE that lies between 90 percent in 2010 to 78 percent in 2009. Findings of Table 2 suggest that Bank Rakyat, BPMB, MIDF and SCC are the most efficient development financial institutions with 100 percent mean score. BSN is close to efficiency frontier with 98 percent and SME bank, Agro Bank, CGC and EXIM bank requires 
improvement to become efficient. Pure technical inefficiency (PTIE= 1-PTE/100) ranges from 22 (2006) percent to 10 (2010) percent.

Findings of Table 3 (refer appendix) show that the average estimates of Scale efficiency (SE) ranges from 84 percent to 97 percent. BPMB and SCC are scale efficient and SME and BSN are close to efficiency frontier with 98 and 95 percent. CGC, Agro Bank, EXIM Bank, MIDF and Bank Rakyat are inefficient and need improvement. Scale inefficiency among the Malaysian DFIs ranges between 3 percent to 16 percent.

Table 4 (refer appendix) findings show that during the period of study (2006-2012), DFIs mean pure technical efficiency is 84 percent and scale efficiency 91.14 percent. The mean PTE during the period is higher than the mean TE. This result is supported with the findings of Banker et al. (1984) that stated that technical efficiency scores obtained under VRS (PTE) are higher than or equal to those obtained under CRS (TE). Findings indicate that the bank inefficiency is attributed to pure technical/managerial efficiency rather than scale efficiency. This also implies that during the period of study, development financial institutions have been found inefficient in controlling or reducing their costs rather than operating at the wrong scale of operations.

\subsection{Determinants of Development Financial Institutions of Malaysia's Technical Efficiency}

As can be seen in Table 5, (refer appendix) result of OLS regression shows that the independent variable Loans to total assets is positively related to technical efficiency and is significant, indicating a negative relationship between bank efficiency and the level of liquid assets held by banks. Result shows that banks with higher loan to asset ratios incline to reveal greater technical efficiency scores; therefore bank loans carry additional weightage to other bank outputs. Regarding the influence of bank size, LNTotal Assets is negatively related to the efficiency of development financial intuitions but it is insignificant. Negative coefficient indicates that larger(smaller) banks tend to exhibit lower (higher) efficiency levels and provides support to other studies that found economies of scale and scope for smaller banks or diseconomies of scale for larger banks (Pasiouras \& Kosmidou, 2007; Staikouras et al., 2008). The coefficient of the LLP/TL is negative, reflecting that development financial institutions with higher credit risks tend to exhibit lower efficiency scores. The empirical findings imply that the banks should focus more on credit risk management. The impact of NII/TA on efficiency is negative and is significant. Results imply that development financial institutions which derive a higher proportion of income from non-interest sources tend to report lower efficiency levels. Total shareholders' equity to total assets is positively related to efficiency; imply that development financial institutions that possess capital strength are also efficient.

\section{Conclusion}

Although, in Malaysia's financial system, development financial institutions comprise only $5.8 \%$ of total financial system, yet they are expected to act as a promoter in realizing socio-economic objectives in the economy. This paper assesses the technical efficiency of Malaysia's nine developmental financial institutions over a period of 2006-2012 from the perspective of intermediary role. Using the intermediation approach, two inputs namely total deposits, total expenses and two outputs: loans, financing and advances and net investments are used to calculate the technical efficiency (TE) which further broken down into pure technical efficiency (PTE) and scale efficiency (SE). The analysis is being conducted based on malaysian development financial institutions efficiency scores per year and on average during the period of study. Later, the study used the OLS regression analysis to regress the technical efficiency scores obtained from the first stage over several internal variables reflecting bank characterstic and stratagic decisions.

The results of the data development analysis (DEA) indicates that the average technical efficiency (TE) scores over the entire period equal to 78 percent which indicates that banks could have saved 22 percent of inputs. Hence, between 2006 and 2012 development financial institutions could improve pure technical efficiency by 16 percent and scale efficiency by 8.86 percent on average. Pure Technical efficiency scores provide that all the inefficiencies directly result from managerial underperformance (i.e., managerial inefficiency) in organizing the bank's inputs hence the development financial institutions (EXIM Bank, CGC Bank, SME Bank and Agro Bank) whose Pure Technical efficiency (PTE) scores are less than Scale efficiency (SE) scores are considered as managerial inefficient in resource utilization. The result also shows that Development Financial Institutions (Bank Rakyat, BSN) are scale inefficient and are not functioning at an optimal scale. Bank Rakyat and BSN are functioning at decreasing returns to scale i.e., proportionate increase in output is less than the proportionate increase in inputs. Bank Rakyat and BSN need to reduce the proportion of inputs to outputs to function at an optimal level. Findings of the determinants that affect the technical efficiency of Development Financial institutions shows that Loans to total assets, natural logarithm of total assets, Loan-Loss provision to total loans, non-interest income to total assets, return on assets and total shareholders' equity to total assets have correlation to technical efficiency but 
loans to total assets, non-interest income to total assets, return on assets are found significant in explaining the Malaysian development financial institutions efficiency from 2006-2012.

This study is constrained by unavailability of data because there is no organized database for non-bank financial institutions in Malaysia. In future, this research can be expanded to look into the potential ability of development financial institutions towards achieving their profitable commitments and expansion of socio-economic targets of Malaysia and can be expanded to examine the risk and efficiency in DFIs in Malaysia.

\section{References}

Akkas, A. (1996). Relative efficiency of the conventional and Islamic banking system in financing investment. Unpublished Ph.D. Dissertation, Dhaka University.

Arif, M. (1989). Islamic banking in Malaysia: Framework, performance and lesson. Journal of Islamic Economics, 2, 2.

Bader, M. K., Shamsher, M., \& Taufiq, H. (2007). Cost, revenue, and profit efficiency of conventional versus Islamic banks: Evidence from the Middle East. IIUM International Conference on Islamic Banking and Finance. Kuala Lumpur, Malaysia.

Banker, R. D., \& Natarajan, R. (2004). Productivity change, technical progress, and relative efficiency change in the public accounting industry. Management Science, 51(2), 291-304. http://dx.doi.org/10.1287/mnsc.1040. 0324

Banker, R. D., \& Natarajan, R. (2008). Evaluating contextual variables affecting productivity using data envelopment analysis. Operations Research, 56(1), 48-58. http://dx.doi.org/10.1287/opre.1070.0460

Banker, R. D., Charnes, A., \& Cooper, W. W. (1984). Some Models for Estimating Technical and Scale Inefficiencies in Data Envelopment Analysis. Management Science, 30(9), 1078-1092. http://dx.doi.org/10. 1287/mnsc.30.9.1078

Berger, A. N., \& Humphrey, D. B. (1997). Efficiency of Financial Institutions: International Survey and Directions for Future Research. European Journal of Operational Research, 98(2), 175-212. http://dx.doi. org/10.1016/S0377-2217(96)00342-6

Bhattacharyya, A., Lovell, C., \& Sahay, P. (1997). The Impact of Liberalization on the Productive Efficiency of Indian Commercial Banks. European Journal of Operational Research, 98(2), 332-345. http://dx.doi. org/10.1016/S0377-2217(96)00351-7

Carmichael, J., \& Pomerleano, M. (2002). Development and regulation of non-bank financial institutions, The World Bank. Retrieved from http://www.ukessays.com/dissertations/finance/financial-services-industry.php \#ixzz3ODHTrKuz

Charnes, A., Cooper, W. W., \& Rhodes, E. (1978). Measuring the efficiency of decision making units. European Journal of Operational Research, 2, 429-444. http://dx.doi.org/10.1016/0377-2217(78)90138-8

Charnes, A., Cooper, W. W., Lewin, A. Y., \& Seiford, L. M. (Eds.). (1994). Data envelopment analysis: Theory, methodology, and applications. Boston: Kluwer. http://dx.doi.org/10.1007/978-94-011-0637-5

Chew, J. (2011, April 21). The Malaysian financial system. Financial Sector Talent Enrichment Programme. Bank Negara Malaysia.

Coelli, T. J. et al. (1998). An Introduction to Efficiency and Productivity Analysis. Boston, Dodrecht, London, Kluwer Academic Publishers. http://dx.doi.org/10.1007/978-1-4615-5493-6

Drake, L., Hall, M., \& Simper, R. (2006). The impact of macroeconomic and regulatory factors on bank efficiency: A non-parametric analysis of Hong Kong's banking system. Journal of Finance and Banking, 30(5), 1443-1466. http://dx.doi.org/10.1016/j.jbankfin.2005.03.022

Estelle, S. M., Johnson, A. L., \& Ruggiero, J. (2010). Three-stage DEA models for incorporating exogenous inputs. Computers and Operations Research, 37(6), 1087-1090. http://dx.doi.org/10.1016/j.cor.2009.09.015

Fukuyama, H. (1993). Technical and scale efficiency of Japanese commercial banks: A nonparametric approach. Applied Economics, 25(8), 1101-1112. http://dx.doi.org/10.1080/00036849300000090

Ghani, A. Z. (2005, September 12). Role of development financial institutions in the financial system; Speech by Datuk Zamani Abdul Ghani, Deputy Governor of the Central Bank of Malaysia, at the International CEO Forum of the Development Finance Institutions 2005. Retrieved from http://www.bis.org/review/r050923e. pdf 
Gregoriou, G. N., \& Zhu, J. (2005). Evaluating Hedge Funds and CTA Performance: Data Envelopment Analysis Approach. John Wiley: New York.

Hamid, M. A., \& Marina, S. (2011). The performance of Banking during 2000-2009: Bank Islam Malaysia Berhad and Conventional Banking in Malaysia. International Journal of Economics and Management Sciences, 1(1), 9-19.

Hassan, M. K., \& Bashir, A. M. (2003). Determinants of Islamic banking profitability. ERF paper.

Hoff, A. (2007). Second stage DEA: Comparison of approaches for modelling the DEA score. European Journal of Operational Research, 181(1), 425-435. http://dx.doi.org/10.1016/j.ejor.2006.05.019

Islam, M. A. (2012). An appraisal of the performance of two (2) Development Financial Institutions (DFIs) in Malaysia. International Journal of Economics and Management Sciences, 1(7), 64-74.

Maning, A. (2011, April 14). Development financial institutions. Financial sector talent enrichment programme (FSTEP). Retrieved from http://www.fstep.org.my/media/File/Overview\%20Week\%20Notes/Datuk\%20 Adinan_CEO\%20BSN.pdf

McDonald, J. (2009). Using least squares and Tobit in second stage DEA efficiency analyses. European Journal of Operational Research, 197(2), 792-798. http://dx.doi.org/10.1016/j.ejor.2008.07.039

Ong, H. B., Selamat, Z., Ismail, N., \& Habibullah, M. S. (2005). Scale and technical efficiency of development finance institutions in Malaysia. International Journal of Management Studies (IJMS), 12(2009), 1-17.

Parkan, C. (1987). Measuring the efficiency of service operations: An application to bank branches. Engineering Costs and Production Economics, 12, 237-242. http://dx.doi.org/10.1016/0167-188X(87)90083-8

Pasiouras, F., \& Kosmidou, K. (2007). Factors influencing the profitability of domestic and foreign commercial banks in the European Union. Research in International Business and Finance, 21, 222-237. http://dx.doi. org/10.1016/j.ribaf.2006.03.007

Rangan, N., Grabowski, R., Aly, H. Y., \& Pasurka, C. (1988). The technical efficiency of U.S. banks. Economics Letters, 28(2), 169-175. http://dx.doi.org/10.1016/0165-1765(88)90109-7

Rosly, S. A., \& Afandi, M. (2003). Performance of Islamic and mainstream banks in Malaysia. International Journal of Social Economics, 30(12), 1249-1265. http://dx.doi.org/10.1108/03068290310500652

Samad, A. (1999). Comparative efficiency of the Islamic bank Malaysia vis-à-vis conventional banks. IIUM Journal of Economics and Management, 7(1), 1-25.

Sathye, M. (2001). X-Efficiency in Australian Banking: An Empirical Investigation. Journal of Banking and Finance, 25(3), 613-630. http://dx.doi.org/10.1016/S0378-4266(00)00156-4

Sherman, H. D., \& Gold, F. (1985). Bank Branch Operating Efficiency: Evaluation with Data Envelopment Analysis. Journal of Banking and Finance, 9(2), 297-315. http://dx.doi.org/10.1016/0378-4266(85)90025-1

Staikouras, C., Mamatzakis, E., \& Koutsomanoli-Filippaki, A. (2008). An empirical investigation of operating performance in the new European banking landscape. Global Finance Journal, 19(1), 32-45. http://dx.doi. org/10.1016/j.gfj.2008.01.001

Sufian, F. (2006). Efficiency of Non-Bank Financial Institutions: Empirical Evidence from Malaysia. International Research Journal of Finance \& Economics, 6, 49-65. Retrieved from http://english.cpiasia. net/dmdocuments/The\%20Efficiency\%20of\%20Non-Bank\%20Financial\%20Institutions.pdf

Sufian, F., \& Habibullah, M. S. (2010). Bank Specific, Industry specific and Macroeconomic Determinants of Bank Efficiency: Empirical Evidence from the Thai Banking Sector. The Journal of Applied Economic Research, 4, 427. http://dx.doi.org/10.1177/097380101000400403

Yudistira, D. (2004). Efficiency in Islamic banking: An empirical analysis of 18 banks. Islamic Economic Studies, $1(12), 1$.

Yue, P. (1990). Data envelopment analysis and commercial bank performance: A primer with applications to Missouri banks, Federal Reserve Bank of St. Louis Review, 74(January), 31-45. 


\section{Appendix A}

Table A1. Technical efficiency scores (IA) (constant returns to scale)

\begin{tabular}{lllllllll}
\hline Banks & Year & & & & & & \\
Agro Bank & $\mathbf{2 0 0 6}$ & $\mathbf{2 0 0 7}$ & $\mathbf{2 0 0 8}$ & $\mathbf{2 0 0 9}$ & $\mathbf{2 0 1 0}$ & $\mathbf{2 0 1 1}$ & $\mathbf{2 0 1 2}$ & Mean \\
Bank Rakyat & 64.9 & 81 & 100 & 63.4 & 85 & 55 & 33 & 69 \\
BPMB & 78.6 & 82 & 79.2 & 76 & 96 & 36 & 100 & 78 \\
BSN & 100 & 100 & 100 & 100 & 100 & 100 & 100 & 100 \\
MIDF & 100 & 100 & 100 & 80 & 100 & 100 & 75 & 94 \\
SCC & 73.6 & 82.3 & 100 & 100 & 100 & 100 & 5.1 & 80.1 \\
SME Bank & 100 & 100 & 100 & 100 & 100 & 100 & 100 & 100 \\
CGC & 100 & 100 & 100 & 77 & 56.1 & 49.3 & 100 & 83.2 \\
EXIM Bank & 12.7 & 12.4 & 10.6 & 21 & 100 & 100 & 62 & 45.5 \\
Mean & NA & NA & 18.3 & 19.4 & 48 & 31.1 & 72.3 & 38
\end{tabular}

Source: Authors own calculation

Table A2. Pure technical efficiency scores (IA) (variable returns to scale)

\begin{tabular}{lllllllll}
\hline Banks & Year & & & & & & & \\
Agro Bank & $\mathbf{2 0 0 6}$ & $\mathbf{2 0 0 7}$ & $\mathbf{2 0 0 8}$ & $\mathbf{2 0 0 9}$ & $\mathbf{2 0 1 0}$ & $\mathbf{2 0 1 1}$ & $\mathbf{2 0 1 2}$ & Mean \\
Bank Rakyat & 66.2 & 82 & 100 & 64 & 96 & 79.4 & 36 & 75 \\
BPMB & 100 & 100 & 100 & 100 & 100 & 100 & 100 & 100 \\
BSN & 100 & 100 & 100 & 100 & 100 & 100 & 100 & 100 \\
MIDF & 100 & 100 & 100 & 100 & 100 & 100 & 86.2 & 98 \\
SCC & 100 & 100 & 100 & 100 & 100 & 100 & 100 & 100 \\
SME Bank & 100 & 100 & 100 & 100 & 100 & 100 & 100 & 100 \\
CGC & 100 & 100 & 100 & 79 & 60 & 53 & 100 & 85 \\
EXIM Bank & 13.5 & 12.5 & 100 & 26 & 100 & 100 & 82 & 62 \\
Mean & NA & NA & 27.4 & 30.3 & 52 & 36 & 86.2 & 46 \\
\hline
\end{tabular}

Source: Authors own calculation

Table A3. Scale efficiency scores (IA)

\begin{tabular}{lllllllll}
\hline Banks & Year & & & & & & \\
Agro Bank & $\mathbf{2 0 0 6}$ & $\mathbf{2 0 0 7}$ & $\mathbf{2 0 0 8}$ & $\mathbf{2 0 0 9}$ & $\mathbf{2 0 1 0}$ & $\mathbf{2 0 1 1}$ & $\mathbf{2 0 1 2}$ & Mean \\
Bank Rakyat & 98 & 99.1 & 100 & 99.2 & 89 & 69 & 93 & 92.4 \\
BPMB & 79 & 82 & 79.2 & 76 & 96 & 36 & 100 & 78.31 \\
BSN & 100 & 100 & 100 & 100 & 100 & 100 & 100 & 100 \\
MIDF & 100 & 100 & 100 & 80 & 100 & 100 & 87 & 95 \\
SCC & 74 & 82.3 & 100 & 100 & 100 & 100 & 5.1 & 80.2 \\
SME Bank & 100 & 100 & 100 & 100 & 100 & 100 & 100 & 100 \\
CGC & 100 & 100 & 100 & 97.1 & 94 & 93.1 & 100 & 98 \\
EXIM Bank & 94.2 & 99.5 & 91.3 & 79.2 & 100 & 100 & 76 & 91.45 \\
Mean & NA & NA & 67 & 64.1 & 92.4 & 88 & 97 & 82 \\
\hline SOur & 93.1 & 95.4 & 93 & 88.3 & 97 & 87.2 & 84 & 91.14 \\
\hline
\end{tabular}

Source: Authors own calculation 
Table A4. Mean technical efficiency-decomposition into pure technical efficiency and scale efficiency

\begin{tabular}{lllllllll}
\hline & $\mathbf{2 0 0 6}$ & $\mathbf{2 0 0 7}$ & $\mathbf{2 0 0 8}$ & $\mathbf{2 0 0 9}$ & $\mathbf{2 0 1 0}$ & $\mathbf{2 0 1 1}$ & $\mathbf{2 0 1 2}$ & Mean (2006-2012) \\
\hline PTE & 79 & 87 & 82.1 & 78 & 90 & 85.3 & 87 & 84 \\
SE & 93.1 & 95.4 & 93 & 88.3 & 97 & 87.2 & 84 & 91.14 \\
TE & 79 & 82.2 & 79 & 71 & 87.1 & 75 & 72 & 78 \\
\hline
\end{tabular}

Source: Authors own calculation

Table A5. OLS regression result

\begin{tabular}{lllllll}
\hline Efficiency & Coef. & Robust Std. Err. & T & $\mathbf{P}>|\mathbf{t}|$ & {$[\mathbf{9 5 \%}$ Conf. } & Interval] \\
\hline L_TA & $36.17274^{* *}$ & 12.97257 & 2.79 & 0.007 & 10.15305 & 62.19243 \\
LNTA & -3.436257 & 2.871897 & -1.20 & 0.237 & -9.196554 & 2.324039 \\
LLP_TL & -28.64984 & 69.05024 & -0.41 & 0.680 & -167.1471 & 109.8474 \\
NII_TA & $-431.9783^{* * *}$ & 121.1579 & -3.57 & 0.001 & -674.9902 & -188.9664 \\
ROA & $-.4545815^{* * *}$ & .0991884 & -4.58 & 0.000 & -.6535283 & -.2556348 \\
TSE_TA & 20.26842 & 24.58826 & 0.82 & 0.413 & -29.04939 & 69.58622 \\
_cons & $143.5796^{*}$ & 70.19261 & 2.05 & 0.046 & 2.791077 & 284.3682 \\
\hline
\end{tabular}

$\mathrm{t}$ statistics in parentheses; ${ }^{*} \mathrm{p}<0.05, * * \mathrm{p}<0.01, * * * \mathrm{p}<0.001 ; \mathrm{L}_{-} \mathrm{TA}=$ Loans to total assets is a measure of banks loans intensity. LNTA $=$ Natural Logarithm of Total Assets is a size of the bank's total assets. LLP_TL= Loan Loss provision to total loans is a measure of banks risk; NII_TA= Non-interest income to total assets is a measure of banks diversification towards non-interest income; $\mathrm{ROA}=$ Return on assets is a proxy for banks profitability; TSE_TA= Total shareholders' equity to total assets is a measure of banks leverage intensity.

Note: robust standard errors number of obs $=61 ; \mathrm{F}(7,53)=38.50$; Prob $>\mathrm{F}=0.0000$; R-squared $=0.2748$; Root $\mathrm{MSE}=25.896$

\section{Copyrights}

Copyright for this article is retained by the author(s), with first publication rights granted to the journal.

This is an open-access article distributed under the terms and conditions of the Creative Commons Attribution license (http://creativecommons.org/licenses/by/3.0/). 